\title{
The Modern Religious Language of Education: Rousseau's Emile
}

\author{
Fritz Osterwalder
}

Published online: 14 July 2012

(C) Springer Science+Business Media B.V. 2012

\begin{abstract}
The Republican education, its concepts, theories, and form of discourse belong to the shared European heritage of the pre-modern Age. The pedagogy of humanism and its effects on the early Modern Age are represented by Republicanism. Even if Republicanism found a political continuation in liberalism and democratism of the Modern Age, the same cannot be said of pedagogic continuity without some reservations. In pedagogy of the Modern Age an alternative to Republicanism prevails that builds onto a body of concepts, discourse, and theory; it goes back to an old theological tradition. Rousseau chooses this alternative exclusively for his concepts of education. He is neither the inventor nor the one who builds up this language in contrast to pedagogical Republicanism. Nonetheless, the pedagogical canonization of Rousseau as one of the co-founders of pedagogical Modernity, marks the specific development that this theological language of pedagogy undergoes at the turn of the nineteenth century. Originally it is closely linked to specific theological, dogmatic lines of thought, namely, to the respective Piety movements within the two Christian denominations of Western Europe. Yet at the turn of the nineteenth century, this theological language of pedagogy increasingly loses that exclusive link to this particular context and becomes thus freely available to any form of pedagogy, which puts at its centre the child's soul, absolute inwardness, and introspection as both holy and also threatened by a basically decadent social environment and outward world.
\end{abstract}

Keywords Republican language of education - Religious language of education · Modernity $\cdot$ Inwardness $\cdot$ Soul of the child

In an article titled "Economie politique" in the fifth volume of the encyclopedia by Diderot and d'Alembert's Encyclopédie of 1755, Rousseau (1964b) presents the concept of Republican education. All citizens are expected to follow the common Republican obligations, to be virtuous, to subordinate their individual will to the "general will" (Rousseau 1964b, p. 252), the "common I" (p. 245), and to defend their common freedom; hence, it is

F. Osterwalder $(\bowtie)$

Institut für Erziehungswissenschaften, Universität Bern, Muesmattstrasse 27, 3012 Bern, Switzerland e-mail: Fritz.Osterwalder@edu.unibe.ch 
crucial for a good government to guarantee that all citizens are educated and enabled accordingly. Education in republics therefore has to be public rather than private.

"The home country cannot survive without freedom, and freedom not without virtue, and virtue not without citizens; you will have it all, if you educate the citizens" (Rousseau 1964b, p. 259). The natural passions, which drive human action, have to be channelled through education from the individual I towards the common I, towards the home country.

The Republican education, its concepts, theories, and form of discourse belong, as it were, to the shared European heritage of the pre-modern Age. ${ }^{1}$ The pedagogy of humanism and its effects on the early Modern Age are represented by Republicanism. Even if Republicanism found a political continuation in liberalism and democratism of the Modern Age, the same cannot be said of pedagogic continuity without some reservations.

In pedagogy of the Modern Age an alternative to Republicanism prevails that builds onto a body of concepts, discourse, and theory; it goes back to an old tradition. Rousseau chooses this alternative exclusively for his concepts of education. He is neither the inventor nor the one who builds up this language in contrast to pedagogical Republicanism.

Nonetheless, the pedagogical canonization of Rousseau as one of the co-founders of pedagogical Modernity, marks the specific development that this theological language of pedagogy undergoes at the turn of the nineteenth century. Originally it is closely linked to specific theological, dogmatic lines of thought, namely, to the respective Piety movements within the two Christian denominations of Western Europe. Yet at the turn of the nineteenth century, this theological language of pedagogy increasingly loses that exclusive link to this particular context and becomes thus freely available to any form of pedagogy, which puts at its centre the child's soul, absolute inwardness, and introspection as both holy and also threatened by a basically decadent social environment and outward world.

\section{Social Decadence and the Theological Language of Pedagogy}

In the encyclopedia article mentioned above, subsequent to emphasizing the importance of public education for virtue and for love of both the home country and the laws, Rousseau adds as a matter of course, "Since the world has been divided into nations too great to admit of being well governed, this method has been no longer practicable, and the reader will readily perceive other reasons why such a thing has never been attempted by any modern people" (Rousseau 1964b, p. 261).

This pessimistic view of the Republican state order and its corresponding education can easily be brought into accordance with the description of social decadence in both 'discourses.' Even in his home republic of Geneva, Rousseau wrote that the Republican education in virtue was in decay, after he had started a public polemic against the Enlightment thinker d'Alembert in which he defended the Republican morals in Geneva, "I was wrong in my letter to M. d'Alembert. I did neither believe our progress to be so big nor our morals to be so advanced. Our evil is hence without remedy" (Rousseau 29 January 1760 to Moultou in Leigh (1969) CG 736).

In Emile (Rousseau 1762/1979) the contrast to the Republican education is the starting point for the whole work. ${ }^{2}$ Modern education, private education in the family, and public education in school make human beings feel torn between their own passions and the unfair, decadent demands of society and thus make them unhappy. The individual is

\footnotetext{
1 See Tröhler (1998, 2000).

2 On the context of the composition of Emile, see Jimack (1960).
} 
neither good to himself nor on his own, nor good to and for the others: "He will never be either man nor citizen/ ... /a bourgeois; this will be nothing" (Rousseau 1762/1979, p. 250).

The alternative to Republican education that is developed in Emile is thus subject to the postulate or hypothesis that the pupil be educated in unity with and for himself as well as in unity with the whole, with an order like the absolute moral order manifested in nature, in which humanity ought to live, beyond the decadent reality of the existing society.

In Emile the education culminates in the educator's confessed commitment to an absolute moral order beyond the order, or rather disorder, of a decadent society. It is an explicitly religious, specifically Christian confession. It starts with a renunciation of the major historical religions of revelation and ends with a personal revelation by the educator, in which he presents how he is embedded in the absolute, divine moral order of nature. It is not a historical but a personal-immediate revelation by means of the divine human being, Jesus, and His all-embracing love. ${ }^{3}$ In La Nouvelle Heloise (Rousseau 1964a) it is Julie's profession of faith, which is ascribed to a very particular line within both denominations, namely, the "devotees" (p. 697). It is clearly defined, which mainstreams within both denominations are meant thereby, Protestant Piety, the Methodists in Great Britain, the Moravian Brothers in Germany, and Catholic Jansenism in France. ${ }^{4}$ In an explanatory footnote Rousseau distances himself from both, as far as political and ecclesiastical and in part also dogmatic matters go (p. 685).

Already for Rousseau the doctrine contents of those confessions, let alone the political and social aim, which mainly the corresponding religious-political currents of the eighteenth century have, are not-or not only—at its center.

At the center of the option 'theological language of pedagogy' stands Rousseau's education as a concept, within which the individual and the individual's education can be established in radical opposition to the unholy and basically decadent society.

\section{The Theological and Religious-Life Context of the Piety Movements in the Seventeenth Century and Their Pedagogization}

The two theological currents within both Western European denominations that Rousseau names, Jansenism and Pietism of the seventeenth and early eighteenth centuries, or the more comprehensive common denominator, Neo-Augustinism, form also the context for the pedagogical language that establishes itself at the beginning of the New Age.

Christian theology and religious life were the context from which pedagogy was generated well before the seventeenth century. The development of educational institutions in Europe is closely linked to the development of the church and theology, especially scholastic theology, and the latter developed also a specific doctrine both for the description and the form of that connex. The scholastic theology about the soul- $\operatorname{dog}$ matized by the Council of Vienne in 1311/12 - was in open opposition to the Augustinian

\footnotetext{
3 Burgelin (1969) calls this argument a classical "palinodie"; it starts with the rational negation of revelation and ends with a very strong personal one of the heart, an "adhésion au christianisme" (p. CXLIII).

4 In La Nouvelle Héloise, Fénelon is mentioned; although Fénelon cannot be counted among the followers of Jansenism, he grasped the particular Jansenist education concept as specific education for girls (on that, see Osterwalder 2000); equally mentioned are the Bernese Pietist Beat von Muralt (Rousseau 1964a, p. 685) and the quietist Madame Guyon (p. 697).
} 
dualistic tradition. The soul, "the unica forma corporis," was seen as an unchangeable form of the human material body.

The patristic, the Augustinian, dualistic psychology, ${ }^{5}$ however, developed further as heretic and ecclesiastical currents and came to bear again only after the breakdown of scholasticism in the fifteenth and sixteenth centuries. Also Pietism and the Piety movement within Protestantism in the seventeenth century went way beyond Luther's, Zwingli's, and Calvin's Augustinism. What made for a "new intellectual climate" (Oberman 1981), the Reformation in the sixteenth century, were the Piety movements for the outgoing seventeenth century, which attempted to put

- the individual religious life and

- the inner transformation of the believers souls by the divine grace

at the center of theology and religious life-and put those increasingly above both the institution and the school of theological thought.

In contrast to the scholastic tradition of teaching, which attempted to grasp theology as a rational and argumentative science, a new type of theology arises in the seventeenth century in the context of both denominations. Inside the Catholic context, this new-old theology found its most elaborated expression in Augustinus (Jansenius 1641) by the bishop of Ypern, Cornelius Jansen. This book centers on the Augustinian dualistic conception and salvation of the totally lost human being by divine grace. It presents a long development about the step-by-step transformation of the human soul through divine grace. What is important is that the priest and the believer himself have to behave corresponding to their actual stage - even if they do not have insight into their proper soul.

True Christianity (Arndt 1605/1753) by the Lutheran pastor Johann Arndt (1555-1621) (comprising four and later six books) appeared first in 1605 and was republished in new editions up to the nineteenth century. It does not follow argumentative logics or systematics; rather, it is based on the edifying effect of the text itself. ${ }^{6}$ Book three of True Christianity refers exclusively and explicitly to Augustine's teaching about the transformation of the soul, which is called the teaching of 'degree of the soul.' Just as the body of human beings grows regularly in clearly defined sequences, so does the soul develop step by step: "Just the way our natural life has its grades, its childhood, manhood, and old age, so does our spiritual and Christian life" (Arndt 1605/1753, p. 682).

The theology about the inner human being has clearly both an inductive and instrumental subtext. Even though God is the one who transforms the soul, and even though this transformation remains outwardly invisible, the "means through which the human being ought to achieve this inner treasure" (Arndt 1605/1753, p. 695) is defined clearly, and at least the terminology reveals the closeness to the future theological language of pedagogy. "The means" indicate "how the human being can be pulled into God" (p. 713); an actual approach of religious life to the transformation of souls is presented. Furthermore, Arndt

\footnotetext{
5 The patristic and the Augustinian teaching of the soul will not be discussed in detail in this paper. The starting point is not Augustine's early work about the soul, which is still totally committed to Platonism, but rather the work "De doctrina christiana Libri Quattuor" (on this, see Marrou 1958), which stands in the tradition of the Roman rhetoric literature that had a lasting effect as teaching of the degrees (Tolomio 1979, p. 16) within the patristic and the monastic tradition. On the scholastic reshapings and rejections of this tradition, see Werner (1882).

6 Arndt's writing about true Christianity and the book of prayers often added to it, the Paradiesgärtchen, the little paradise garden, are among the most widespread publications in the German-speaking Protestant area. The text is rich of educational metaphors and illustrations (on this, see Müller-Mees 1974) belonging to a strict theological context.
} 
also subdivides this process into six or seven steps respectively, including the corresponding specific aims and means:

This is beautifully illustrated by the golden throne or chair of Salomon, I Reg. 10, 19, which had 6 grades or steps that one climbs, and on the seventh one finds the 'sedem $\&$ thronum pacis', the seat and throne of peace. Thus there are six degrees of humility; when one ascends those, then one finds heavenly peace-King Salomon on his throne and true peace of heart. The first grade is to estimate oneself inferior to other people, and to love being insignificant. (p. 715)

At the center of the transformation is the inner struggle, which simultaneously ends with the death of the old Adam and climaxes in the inner, spiritual rebirth; henceforth, the human being acts through the mercy of God and confirms himself, his soul, by doing so. The soul must grow in faith and prove to be good, if it is not to fall back again.

The actual theological innovation of the seventeenth and early eighteenth century is doubtless the comprehensive design of teaching on the changeability of the soul and the habit of an inward piety. The task at hand is to tune theology and religious life to the believers' grade-without however having any knowledge, let alone certainty, about that degree.

What is well-known from German Pietism are the collegia pietatis and the fights for confession and conversion, the profession of rebirth, and the systematic self-scrutiny of one's own actions with regard to the question as to whether they happened out of grace or out of sinful will, which is addicted to the flesh. ${ }^{7}$

Within the earlier Catholic Jansenism in France, and in particular within the environment of the Cistercian abbey in Port-Royal, originally more traditional, rather ascetic forms are practiced, which aim equally, however, at absolute introspection.

In 1637 Antoine Le Maistre, a member of the parliament of Paris_a kind of lawcourt—and "conseiller d'état" at court, gives up all his offices with much public clamour in order to retreat, "in contempt for the world" (Sedgewick 1998, p. 85), to the solitude of the monastery Port-Royal des Champs, which had just been left by the nuns. The retreat from the company of other human beings into outward solitude should lead the human beings to introspection. In complete inner and outer solitude, the soul prepares itself in a "work of conscience" (p. 85) for the inner transformation, the confession and conversion. ${ }^{8}$ This radical retreat into physical isolation becomes the starting point for the "solitaries" 9 (p. 86, 90) of Port-Royal, a group of priests and lay people, which gives a sort of organizational backup to the movement - and also to the 'little schools of Port-Royal' later on-along with the nunnery itself. Therein lies already the basis for the pedagogization of religious life, which will be presented below.

However, this form of total retreat from the world into outer and inner solitude is not the generally religious life for Jansenists. Rather, the believers are generally answerable to a "director," who-during a temporary retreat from the world-leads them via the world of introspection to penitence, penance, conversion, and an inwardly solitary life in the bad outward world. To this inner transformation of the soul the piety movements not only dedicate a great part of their comprehensive and varied literary production-sermons, devotional books, spiritual exercises, confession and profession writings, and so on-but

\footnotetext{
${ }^{7}$ See a summary in Brecht (1997, p. 295).

${ }^{8}$ On the factual development concerning this specific form of the movement from a Jansenist, canonical perspective, see Fontaine (1738), p. 51, and for a view from a historical distance, see Sedgewick (1998). 9 "solitaires"
} 
they describe also the duties of "the director of conscience" or of the Protestant preacher in that sense.

The priest, the "director" of this "work of conscience" is compared to a pedagogue; like a pedagogue, the priest, who is himself converted, educates the soul: "He forms him (the believer) thus, prepares him and heals him little by little through these diverse forms of grace, as Jesus Christ formed the Apostles" (Arnauld 1643/1687, p. 45).

In a conversation with Le Maistre's confession father, who complains desperately about the weaknesses of his protégé, the abbot of Saint Cyran uses the metaphor of children's education to describe the priest's task. Leading the soul to grace is like educating small children: "Thus in order to do it as it ought to be done, it needs to be done with much leisureness, patience, and calm, and he needs to have his soul in his power for a certain time in order to lead it step by step as one leads children" (Saint Cyran, cited in Fontaine 1738, p. 217).

This concept becomes the basic pattern for the pedagogic-religious task within the Protestant and Catholic Piety movements of the outgoing seventeenth and the eighteenth century. In France Pierre Nicole's (1714) work Essais de Morale (Moral Essays), which was first published in four volumes with an incorrect author's name, leads the way. Nicole's critical analysis concerning the order of the world and the society needs to be understood as an immediate argument regarding both the French Moralist writings and the two-way debate about Hobbes' and Locke's writings, which are recognized as the explanation of modern society theory. ${ }^{10}$

Social peace and civilization can, although only in a precarious form, be maintained even by human sinners, who are completely addicted to sinful narcissism and sinful passions, however without any innate justice or good order. This is the starting point for Nicole's moral theology. Even pure, evil egoism leads human beings to establishing, respecting, and maintaining an order so as to ensure a certain security for their belongings and their lives (Nicole 1714, p. 119). God's grace within human beings, however, follows the same effects as this egoistic self-love through the purpose of the convert's actions. The passion of self-love prompts human beings to pretend that they love other human beings, so that those will love them in return. God's grace, the true love, leads to charity and to God's glory on the same path.

The retreat into the inner world, into introspection, is a task of religious faith. Those who retreat check over and over again what motives drive human action, consider which order they are obliged to, to the precarious outer one of society or to the eternal order of grace, which they can only perceive in fragments. This "self-knowledge" 11 leads to introspection, via outer solitude, and from there back into corrupt society, where the human being acts and communicates with other human beings either for fulfilling his egoism or for the glory of God (Nicole 1714, p. 9). Nicole replaces the sinful self-reference of "narcissism" 12 with "self-love." 13

\footnotetext{
${ }^{10}$ As is well known, Hobbes wrote his great works in Paris; Nicole was well acquainted with them (James 1972, p.137), and it is obvious that Hobbes, too, was aware of the beginning controversy regarding Jansenism. Locke himself translated parts of Nicole's essays and spread them in Britain (Locke 1991).

11 "la connaissance de soi-même".

12 "amour propre".

13 "amour de soi".
} 


\section{Theological Pedagogy}

In the framework of this theology of morals, also pedagogy itself starts to take shape as an independent discourse or text. Before I turn to those developed, fixed pedagogical forms of discourse in the educational writings of Catholicism and Protestantism, I want to draw the attention to their genesis outside of theory and theology.

In a letter from prison in 1638, during the first waves of repression, the quarrelsome Jansenist abbot of Saint Cyran describes the origin of what are being called "the little schools of Port-Royal." It is a matter of 'schools,' which-according to Port-Royal's historiography - were 'opened' in 1637 by having the hermits take in children (Delforge 1985, p. 351). The schools built an excellent reputation for themselves already in their days, which continued throughout the eighteenth century; this reputation was due to the books of learning, the teachers - the hermits, and most of all the demand that they made thereby. However, the abbot of Saint Cyran had already raised a poor widow's young child, whom he had found in the woods, before he was taken prisoner. The educator's task is said to be extraordinarily difficult and painful, but he had taken it on himself all the same, because a sign of God could be seen in it—self-evidently a sign that he had been chosen and tested: "The circumstances were thus that I could not abandon it (the child) without displeasing God and without violating the dispositions he had laid in me, which I had come to regard as a mark of his will" (Saint Cyran, cited in Fontaine 1738, p. CXIV).

The most important task regarding young children is to "preserve the(ir) innocence," which was accorded to them through their christening. The children's ignorance is holy insofar as they cannot be consciously evil. That is why they need to be separated from the bad world. During that phase this is far more important than that they learn subject matter. Thus they rather ought to be left to play their own games up to the age of twelve (Saint Cyran, cited in Fontaine 1738, p. CXV).

Nicolas Fontaine (1625-1709) reports extensively on the last conversations with the abbot, after his liberation and shortly before his death, in his memoirs (Fontaine 1738). Saint Cyran tells again about the widow's child that he has taken in. Children need to be treated "gently," even if they make mistakes, as mistakes are still the result of their innocence. In the meantime he had the boy train as a carpenter (Fontaine 1738, p. 193). With other children that the abbot and the hermits raised, the outcome was less happy. Yet, whatever the educator does for the sake of the child, it cannot determine the outcome, since that depends on God's predestination.

The pedagogical isolation of the child from the world, the focus on itself and its inner world are described very dramatically with the metaphor of the besieged town. The enemy, the devil, makes his rounds and tries to find access to the child's soul, while the young baptized children are defenceless. In dealing with things, in acting, and later in learning the educator leads the children gradually towards their inner world, in the expectation and hope that God's grace be accorded to them. This construction takes on a new quality of form and content through connection with the theology of morals as developed by Pierre Nicole. The second volume of Essais de Morale of 1671 is an only marginally reedited second edition of a book that had been published already a year earlier under a false writer's name as On the Education of a Prince. ${ }^{14}$

The context of politics and church life clarifies the nature of the task in Nicole's treatise on education. After peace had been made in the French church in 1668, which lasted for a

${ }^{14}$ De l'éducation d'un Prince; I discussed Nicole's paper on education and its context comprehensively in Osterwalder (1995). 
short while, and during which the Jansenists could maintain their position-despite the loss of their schools - they, as partly officialized leadership of the church, claimed the task of educating the Dauphin, prince and future king, for themselves.

Yet the very nature of that task can appear to be particularly irritating at first. Jansenism has come to be known for its solitaires of Port Royal, i.e., for retreat from the world into solitude. Yet how can the prince, who is chosen by God to reign in the world, be educated in a Jansenist manner, i.e., be led into isolation from the world and to an absolute inner world? Accordingly, the way into solitude becomes the educational path into the world. Education becomes the preparation for the profession in the world. However, the true profession in the world is to be human: "There is a common profession, and a general craft which all human beings are obliged to perform, which is that of being a human being and of living as a human being" (Nicole 1670, p. 143). In the profession of being human, two paths exist-one to eternal damnation and one to redemption and eternal happiness, "a happiness that will never finish" (p. 145).

The human being's predestination to eternal happiness cannot be found in society, however. For this reason all human beings need to search for humanity in solitude, in their relation to themselves. According to the gradual path of the soul towards God, education itself is equally arranged in steps (Nicole 1670):

- The framework for the prince's education lies in the outer solitude with his educator, the "director of conscience," and the things to which he is being introduced. Yet the quality of the educator does not consist in his knowledge of those subject matters, science; rather, it "has no name which one attaches to a certain profession" (p. 8). The starting point is the fact that the educator's free will is led by God's grace, i.e., is free to do good, to act upon the love of God.

- For the second degree, the educator leads his pupil's soul away from things and towards reflection of the soul itself, its nature, operations, and its status (p. 9f). The knowledge about scientific subject matters is vain (p. 8), whereas knowledge about one's own soul and its operations, and in particular the limits of one's mind that can thereby be acquired, guide the prince far better (p. 11).

- For the third grade, the prince is introduced to the "sciences of man" (p. 16), politics, his future task. Here the outer "solitude" is shifted wholly into one's own inner world. In this science, history, he learns that when he is dealing with human beings, and in particular with power- "the big ones" - lies and deceit, malice, and deception prevail. Moral and virtue cannot be found within the society but only from within oneself, from one's inner world. Although this reflection onto oneself relates equally to one's own corruption.

- The fourth step leads the prince out of that inner misery. The human being has been acquainted with the eternal order of growing and dying thanks to the natural sciences, and he has understood that they originate in the eternal, almighty spirit. On the path of rational insight and observation of the mind-as rational mind-only its own corruption is possible but never its redemption and perfection: "This remedy can thus not be found through reason, it can only be discovered suddenly" (p. 67). ${ }^{15}$ The education, or rather the transformation of the soul, finds its climax in the revelation of redemption through Christ's sacrifice and through predestination to grace.

- In the fifth degree, the prince is led into the world as a ruler, in which he is active not for his own lust for power but for the glory of God; in the sixth degree he shows

$\overline{15}$ "Ce remède ne peut donc se trouver par la raison, il se découvre tout à coup." 
Christian charity in the social world, and in the seventh degree he reaffirms continuous devotion to God's love.

The specific curriculum, the subject matters and the books, the instructions regarding the art of governing that Nicole (1670) mentions in his book of education are hence only the substratum of education proper, the transformation of the soul and its self-reflection. It is essential in this context that the beginning - the educator's acting on God's grace-as well as the climax-predestination and redemption - are not accessible to pedagogical causality, whereas for the actual educational measures a basis of proper pedagogical instrumentality is laid.

It is this design of education and its relation to secular science and order that becomes the norm for the religious language of pedagogy. Science and the order of society, morals, are neither true nor just; they remain merely a substratum on which the love of God, charity, and humanity come to pass inwardly.

\section{The Religious Text in Modern Pedagogy: Rousseau's Emile}

The substantial secondary literature on Rousseau, and in particular on his book of education Emile, refers to his position in the Christian tradition. The focus thereby lies on the question as to which religious-theological current of his times Rousseau and his religion can be ascribed ${ }^{16}$ or how he deals with the dogmatic assumption of the original sin. ${ }^{17}$

My preoccupation is far more general. It is only a case of reconstructing the order of arguments within which Rousseau formulates his alternative to pedagogical Republicanism. I would thereby like to demonstrate that this order of arguments continues the theological tradition presented above and imparts it also to secular Modernity of educational arguments.

We can schematically define five elements that the arguments follow in Emile and that coincide largely with the concepts as I have shown them for the theological pedagogy. In that context it is not crucial what Rousseau adopted directly through his own preoccupation with pedagogical Jansenism and what was handed down to him via manifold currents, via the theological writings within the two denominations, and via the rich pedagogical literature throughout the eighteenth century. Nonetheless, it is worth mentioning that Rousseau himself refers to the Neo-Augustinian and Jansenist tradition as his primary source for the debate on pedagogy in his Confessions: "the writings of Port-Royal and of the Oratorium are those, which I read most frequently (at the time when I started to preoccupy myself with education), and which turned me into half a Jansenist" (Rousseau 1959, p. 242).

In his design of education Rousseau follows the theological-pedagogical concept of the Piety movement almost to the letter:

- The first concept consists both of the absolute moral as a starting point and as a goal of education. At birth the child is integrated into a morally absolute good order, which is given to nature as a spiritual principle, with his destiny, his body, his spiritual and moral potential, without being aware of that order himself (Rousseau 1969, p. 288) and without making his own position outwardly visible. "Genius" and "character" (Rousseau 1979, p. 52) remain hidden; not even a "philosopher" (Rousseau 1979, p. 62) can

\footnotetext{
16 See Ravier (1941), Masson (1970).

17 Brooke (2001).
} 
recognize how far a human being can come. This calling reveals itself only at the end, the climax of education, when the pupil consciously finds his place both in the eternal order of nature and the bad order of society, through answering with a confession to the educator's confession. However, the aim is that he follows his destiny in the moral, spiritual order of nature and takes care of his tasks in bad society when dealing with other human beings as a human being according to that eternal order; he remains true to himself, a "man" (Rousseau 1979, p. 42). The aim is not to establish new better laws or to find a republic (Rousseau 1969, p. 849).

- The second concept aims at a personal, exclusive, and intimate relationship, into which the educator, the good "governor" (Rousseau 1979, p. 49), enters with his pupil and which guides the whole development from infant to social human being. Since the social position of the pupil within the bad society remains forever precarious, the privileged relationship with the educator continues and renews itself over and over again. Thereby, it is essential that the educator, or more precisely his noble soul, his "sublime soul" (Rousseau 1979, p. 49), is completely absorbed by the good, eternal order, i.e., he puts himself last, puts the demands of the pupil first, and acts solely, so to speak, in view of the absolute order of good and of the child's position within it-i.e., he is thus "more than a man himself" (p. 50).

- The third concept refers to the child's educationally designed path into society, which leads into solitude. From outer solitude in the countryside, which is unaffected by the bad social life, which can be completely subject to the educational arrangement-in contrast to the city, and which relates the child to itself (Rousseau 1979, p. 326), the child arrives at inner solitude. The path from outer to inner solitude is traveled via the human being's self-reflection in his physical relations to things, in his relation to his own sensual perceptions and their reasonable digestion, and finally via the study of history and the misery of society to the relation with oneself as a compassionate social human being. Here the educational path progresses step by step. As important as Rousseau's borrowing from contemporary pediatrics, from Buffon's natural history on human beings, and from sensualism is for this concept, at the center of it all stands nonetheless an order of gradual steps, which is ultimately defined by moral, by moral self-perception, and by embedding in an absolute, good order, i.e., nature as intended and created by God.

- The fourth and crucial concept of this discourse on education solves the question of how the pupil can remain good by returning to himself and by simultaneously living in a decadent society. This stage is defined by conversion and confession, by "the second birth" (Rousseau 1979, p. 212). In the educator's profession to love of the eternal, spiritual order, which is innate to nature, to its grace and justice, and to its spiritual creator, who created also the educator himself as an immortal soul, who gave him a place, a task, and happiness amidst an injust society in disorder, the educator faces his pupil as a human being and reveals himself as a person. In this immediate confrontation with each other, the pupil returns wholly to himself (p. 583, 596). In his second birth, his own confession, his own inner voice wakes up as well, "the voice of the soul" (p. 286), an innate principle of justice and virtue (p. 598), the voice which speaks to "the heart," not to reason. Whereas reason can recognize this order only in fragments and can be wrong about it, the heart, which follows this voice, can never be wrong and is totally absorbed in that eternal order: "We can be men without being scholars" (p. 290).

- The fifth concept of that discourse lies in the specific, rhetoric layout, which again follows the theological tradition. The text does not just talk about education; instead, the writer addresses the reader directly and educates him thus to become an educator himself. From morality's solitude from within himself, the sublime voice, the writer's 
conscience, speaks and carries-as Baczko (1970) states-the "mark of holiness": "The ingenious legislator and the ingenious educator take on themselves superhuman tasks for the sake of the human beings; they are 'divine figures' on earth, the political and the didactic treatise fulfil the function of a new gospel" (Baczko 1970, p. 334). The truth of the discourse, the soundness of education, which are being described, are not confirmed by rational references or experiences but through the speaker's/writer's intention and his elevated inner solitude, from where they originate, in the same sense as the Jansenist or Pietist theologist refers to Auctoritas and as the guide of souls solely to grace, which manifests itself through him.

If we thus talk about continuity of the theological language in modern pedagogy, then the difference with theological pedagogy will be emphasized at the same time. Rousseau is neither a Protestant Pietist nor a Catholic Jansenist. Throughout the controversy with the authorities of both denominations Rousseau knows how to position himself theologically by differentiating himself from both of them. Typically this definition is still theological, even if the dogmatic is actually being exploded regarding two crucial points—namely, the central dogma of original sin and God's predestination of grace, which are being strengthened yet again by the Piety movements against the less orthodox currents of theology. With his breaking up of the dogma, Rousseau is in no way a rare exception. Equally, it is no longer particularly exciting pedagogically either to no longer start from original sin and God's predestination of grace. Yet, what doubtlessly constitutes the real scandal-and Rousseau operates consciously on it-is the fact that he justifies the break with the central dogma precisely with the very theologically confirmed concepts, the pedagogical language of the Piety movements. However, he knows full well, as he proves in the theological-dogmatic polemic with the theologians, that he puts the absolute, moral starting point of the human being's natural goodness/grace and the child's innocence at birth in place of the christening in a dogmatically fixed and occupied space of the theological discourse on education (Rousseau 1969, p. 938). He knows, furthermore, that with this the morally absolute beginning is thus not being newly defined but that instead the dogma of predestination to grace is being dropped. What does he gain thereby? In theological pedagogy, God is ultimately the decisive protagonist even for education. Success and failure regarding the transformation of the soul are equally decided by predestination to grace. With the separation between pedagogy and the dogma of divine predestination, the educator becomes potentially the key protagonist; the absolute grace is now at pedagogy's disposal.

The modern pedagogical discourses, such as they developed in education and public debate, even as sciences, have since either largely lost or even consciously discarded their connection to the Christian dogma and to religion; nonetheless, the theological language of pedagogy continues to be used, fostered, and expanded. The point of reference for it continues to be the absolute moral order, the wholeness beyond and in contrast to any social reality, which is at the disposal of education. Education is measured against the given individuality, which is at an insurmountable distance to fragmentary, social reality and rationality and rests in that absolute order. The educator finds access to it solely through the fact that his or her own intention is well embedded in that order. Education itself is an exclusively personal, so to speak, extra-social relationship of human beings, who are part of an absolute order. In that relationship, which protects the child's individuality against the fragmentation of society until it can retreat within itself even among society, the child is simultaneously subject to that relationship through the right instruments and methods. Knowledge and competence, social rules, the subject matters of 
learning are mere substrate, thanks to which the education and the psychological individuality develop gradually step by step; these are set into relation to the child itself and its inwardnes (Osterwalder 2002).

Modern pedagogy in the religious language promises moral wholeness against fragmented knowledge and skills in a fractured society. Even where education is a fixed part of processes in social and political institutions such as school, the religious language of education claims critically-in opposition to the limitation of any institutional power in modern democracy_undivided and unrestricted availability.

\section{References}

Arnauld, A. (1643/1687). De la fréquente communion où les sentiments des pères, des papes et des conciles touchant l'usage des sacremens de Pénitence et d'Eucharistie son fidèlement exposes. Lyon: L. Plaignard.

Arndt, J. (1605/1753). Die sechs Bücher vom wahren Christenthum. [s.1.]: Bernhard.

Baczko, B. (1970). Rousseau: Einsamkeit und Gemeinschaft. Vienna: Europa.

Brecht, M. (1997). Das Aufkommen der neuen Frömmigkeitsbewegung in Deutschland. In M. Brecht (Ed.), Geschichte des Pietismus (Vol. 1, pp. 113-203). Göttingen: Vandenhoeck \& Ruprecht.

Brooke, C. (2001). Rousseau's Political Philosophy: Stoic and Augustinian Origins. In P. Riley (Ed.), The Cambridge companion to Rousseau (pp. 94-123). Cambridge: Cambridge University Press.

Burgelin, P. (1969). Introduction Emile ou de l'éducation. In J.-J. Rousseau (Ed.), Oeuvres Complètes, t. IV (pp. LXXXIIX-CLI). Paris: Gallimard.

Delforge, F. (1985). Les petites écoles de Port-Royal. 1637-1660. Paris: Cerf.

Fontaine, N. (1738). Mémoires pour servir à l'Histoire de Port-Royal. Cologne: Aux dépens de la compagnie.

James, E. D. (1972). Pierre Nicole, Jansenist and humanist: A study of his thought. The Hague: Springer.

Jansenius, C. (1641). Augustinus seu Doctrina Sancti Augustini, De Humanae Naturae sanitate, agritudine, medicina adversus Pelagianos \& Massilienses. Paris: [s.n.].

Jimack, P. D. (1960). La Genèse et la rédaction de l'Emile de J.-J. Rousseau. Geneva: Institut et Musée Voltaire.

Leigh, R. A. (1969). Correspondance complète de Jean Jacques Rousseau VII. Geneva: Institut et Musée Voltaire.

Locke, J. (1991). Discourses: Translated from Nicole's Essays, with important variations from the original French. Bristol: Thoemmes.

Marrou, H.-I. (1958). Saint Augustin et la Fin de la Culture Antique. Paris: Boccard.

Masson, P.-M. (1970). La Religion de Jean-Jacques Rousseau. Geneva: Slatkine.

Müller-Mees, E. (1974). Die Rolle der Emblematik im Erbauungsbuch, aufgezeigt an Johannes Arndts "4 Büchern vom wahren Christentum" (Unpublished doctoral dissertation). Cologne: University of Cologne.

Nicole, P. (1670). L'Education d'un Prince divisée en trois parties, dont la dernière contient divers traittez utiles à tout le monde. Paris: Charles Savreux.

Nicole, P. (1714). Essais de Morale, Vol. 3. Luxembourg: A. Chevalier. (First volume published 1671).

Oberman, H. A. (1981). Masters of the reformation: The emergence of a new intellectual climate in Europe. Cambridge: Cambridge University Press.

Osterwalder, F. (1995). Die pädagogischen Konzepte des Jansenismus im ausgehenden 17. Jahrhundert und ihre Begründung: theologische Ursprünge des modernen pädagogischen Paradigmas. Jahrbuch für historische Bildungsforschung, 2, 59-84.

Osterwalder, F. (2000). Theologische Konzepte von Erziehung. Das Verhältnis von Fénelon und Francke. In J. Neumann \& U. Sträter (Eds.), Das Kind in Pietismus und Aufklärung (pp. 79-94). Halle an der Saale: Verlag der Franckeschen Stiftungen Halle.

Osterwalder, F. (2002). Die absolute Psychologie der Pädagogik-das säkulare theologische Erbe. In F. Oser \& R. Reichenbach (Eds.), Die Psychologisierung der Pädagogik (pp. 29-45). Weinheim: Juventa.

Ravier, A. (1941). L'Education de l'Homme Nouveau. Issoudun: Éditions Spes.

Rousseau, J.-J. (1959). Oeuvres Complètes, t. I. Paris: Gallimard.

Rousseau, J.-J. (1964a). Oeuvres Complètes, t. II. Paris: Gallimard.

Rousseau, J.-J. (1964b). Oeuvres Complètes, t. III. Paris: Gallimard. 
Rousseau, J.-J. (1969). Oeuvres Complètes, t. IV. Paris: Gallimard.

Rousseau, J.-J. (1979). Emile: Or, on Education (A. Bloom, Trans.). New York, NY: Basic Books. (Original work published in 1762).

Sedgewick, A. (1998). The travails of conscience: The Arnauld family and the Ancien Régime. Cambridge, MA: Harvard University Press.

Tolomio, I. (1979). L'anima dell'uomo. Introduzione. Milano: Rusconi.

Tröhler, D. (1998). Rousseaus Problem von Menschen und Bürgerbildung und die pädagogische Implikation in Pestalozzis Nachforschungen. Neue Pestalozzi Studien, 6, 121-160.

Tröhler, D. (2000). Republikanismus als Erziehungsprogramm. Die Rolle von Geschichte und Freundschaft in den Konzepten eidgenössischer Bürgerbildung der Helvetischen Gesellschaft. In M. Böhler, E. Hofmann, P. H. Reill, S. Zurbuchen, \& L. Droz (Eds.), Republikanische Tugend (pp. 401-421). Geneva: Slatkine.

Werner, K. (1882). Die Augustinische Psychologie in ihrer mittelalterlich-scholastischen Einkleidung und Gestaltung. Vienna Austria: [s.n.]. 